\title{
Convergent evolution of aposematic coloration in Neotropical poison frogs: a molecular phylogenetic perspective
}

\author{
Miguel Vences ${ }^{1, *}$, Joachim Kosuch ${ }^{2}$, Renaud Boistel ${ }^{3}$, Célio F. B. Haddad ${ }^{4}$, Enrique La Marca ${ }^{5}$, Stefan Lötters ${ }^{2}$, \\ Michael Veith ${ }^{2}$ \\ ${ }^{1}$ Institute for Biodiversity and Ecosystem Dynamics, Zoological M useum, University of Amsterdam, The Netherlands \\ 2 Institute of Zoology, Department of Ecology, University of Mainz, Germany \\ ${ }^{3}$ Centre Scientifique d'Orsay, Laboratoires des Mécanismes de Communication, Université Paris Sud, Orsay Cedex, France \\ ${ }^{4}$ Departamento de Zoologia, Instituto de Biociências, Universidade Estadual Paulista, Rio Claro, SP, Brasil \\ ${ }^{5}$ Laboratorio de Biogeografía, Escuela de Geografía, Universidad de Los Andes, Mérida, Venezuela
}

Received 15 November 2002 · Accepted 28 A pril 2003

\begin{abstract}
Poison frogs of the family Dendrobatidae contain cryptic as well as brightly colored, presumably aposematic species. The prevailing phylogenetic hypothesis assumes that the aposematic taxa form a monophyletic group while the cryptic species (Colostethus sensu lato) are basal and paraphyletic. Analysis of 86 dendrobatid sequences of a fragment of the 165 rRNA gene resulted in a much more complex scenario, with several clades that contained aposematic as well as cryptic taxa. M onophyly of the aposematic taxa was significantly rejected by SH-tests in an analysis with additional 12S and 16S rDNA fragments and reduced taxon sampling. The brightly colored Allobates femoralis and A. zaparo (Silverstone) comb. nov. (previously Epipedobates) belong in a clade with cryptic species of Colostethus. Additionally, Colostethus pratti was grouped with Epipedobates, and Colostethus bocagei with Cryptophyllobates. In several cases, the aposematic species have general distributions similar to those of their non-aposematic sister groups, indicating multiple instances of regional radiations in which some taxa independently acquired bright color. From a classificatory point of view, it is relevant that the type species of M inyobates, $M$. steyermarki, resulted as the sister group of the genus Dendrobates, and that species of Mannophryne and Nephelobates formed monophyletic clades, corroborating the validity of these genera. Leptodactylids of the genera Hylodes and Crossodactylus were not unambiguously identified as the sister group of the Dendrobatidae; these were monophyletic in all analyses and probably originated early in the radiation of Neotropical hyloid frogs.
\end{abstract}

Key words: Amphibia, Dendrobatidae, Hylodinae, aposematic color, skin toxins, phylogeny

See also Electronic Supplement at http://www.senckenberg.de/odes/03-13.htm

\section{Introduction}

Anuran amphibians are organisms well suited for studies of vertebrate evolutionary patterns. Among other aspects (e.g. extraordinary diversity in species numbers and reproductive modes), they display a high degree of morphological convergence. In discussions of the origin of conspicuous color patterns, of high toxicity, complex social and territorial behaviour, or brood care, Neotropical poison frogs (Dendrobatidae) have long been in the center of interest.
Recent molecular studies (e.g. Summers et al. 1997, 1999; Clough \& Summers 2000; Vences et al. 2000) and behavioural studies (e.g. Toft 1995; Caldwell 1996, 1997; Vences et al. 1998; Summers \& Clough 2001) allow for some general conclusions concerning dendrobatid relationships: (i) monophyly of the family is highly probable as a member of the hyloid lineage within the Neobatrachia, although (ii) the sister group of the Dendrobatidae remains unidentified; (iii) the presence of skin alkaloids in correlation with bright (aposematic) colors may have evolved in parallel lineages, but (iv)

* Corresponding author: Miguel Vences, Institute for Biodiversity and Ecosystem Dynamics, Zoological Museum, University of Amsterdam, PO Box 94766, NL-1090 GT Amsterdam, The Netherlands; e-mail: vences@ science.uva.nl 
highly potent alkaloids occur in one clade (genera Dendrobates and Phyllobates) only; (v) only limited convergence or reversal prevailed in the evolution of some highly derived behavioural traits (e.g., microphagy, female egg attendance, use of phytotelmata as pools for tadpole development, pair bonding).

However, how reliable is our knowledge? Of the approximately 200 known species in the family (Glaw et al. 1998) comparatively few have been used in phylogenetic reconstructions. Primarily, these are the brightly colored taxa of the genera Allobates, Cryptophyllobates, Dendrobates, Epipedobates, and Phyllobates. Other groups have been considered peripherally or not at all in molecular studies. These include Colostethus sensu lato (i.e., approximately half of the dendrobatid species), for which nine species groups have been suggested by Rivero \& Serna (1989) and Rivero (1990), and the proposed genera Aromobates, Mannophryne, and Nephelobates (the latter of which were taken out of Colostethus sensu lato by La Marca 1992, 1994). The majority of these frogs are cryptically colored and considered to be more 'primitive' within the dendrobatid tree (Myers et al. 1991, Caldwell 1996, Vences et al. 1998). Our knowledge of their life histories and toxicities generally is poor. Nevertheless, it has been documented that some of these 'primitive' forms show highly derived characters, as there are (i) Colostethus stepheni which has nidicolous tadpoles (Juncá et al. 1994); (ii) C. degranvillei in which larvae develop to froglets on the dorsum of a parent (Lescure 1984); (iii) C. inguinalis which contains a highly potent tetrodotoxin (Daly et al. 1994a); (iv) C. beebei which breeds in phytotelmata (Bourne et al. 2001); and some Colostethus species that undoubtedly possess aposematic colors (e.g. C. nexipus; Coloma 1995).

Such indications of multiple evolution of toxicity and aposematism correspond well with the general pattern among the Anura. Water-soluble alkaloid toxins accumulate in frogs after uptake from arthropod prey (Daly et al. 1994b), a mechanism which appears to have been acquired independently by dendrobatids, Malagasy poison frogs (genus Mantella, family Mantellidae), Australian toadlets (genus Pseudophryne, family Myobatrachidae) and South American toads (genus Melanophryniscus, family Bufonidae) (Daly et al. 1987, 1996). These and several other unrelated frog lineages independently evolved conspicuous colorations that can be considered as aposematic (Duellman \& Trueb 1986, Lötters \& Vences 1998). Interestingly, in both Mantella and in Dendrobates the aposematic pattern itself is subject to parallelism, probably caused by Müllerian mimicry selection (Symula et al. 2001, Schaefer et al. 2002).

When trying to elucidate these fascinating phenomena, incomplete taxon sampling has the potential of causing severe problems in phylogenetic analysis. Underrepresentation of 'primitive' dendrobatids may lead to equivocal or incorrect scenarios of character evolution if some key taxa are missing that actually are more closely related to the 'derived' species than others. Recently, simulation studies (Zwickl \& Hillis 2002) illustrated that increased sampling of taxa is one of the most important ways to increase overall phylogenetic accuracy. It also helps to avoid problems with accumulated autapomorphies in few single lineages ('long-branch attraction'; see Hillis 1996, Wiens \& Hollingsworth 2000).

Herein, we reanalyze the published molecular data for poison frogs and complement these with sequences of 37 additional dendrobatid samples. These belong to Colostethus sensu lato involving species groups II, IV, VI, VII (i.e. Mannophryne of La Marca 1992), VIII (i.e. Nephelobates of La Marca 1994 in part; La Marca 1985) and IX (Rivero \& Serna 1989; Rivero 1990), plus several species that have not been allocated to species groups (C. baeobatrachus, C. bocagei, C. humilis, C. stepheni). We also provide the first molecular data on the hylodine (sensu Frost 1985) genera Hylodes and Crossodactylus (family Leptodactylidae), which have been suggested to represent potential sister groups of the Dendrobatidae within the Hyloidea (Lynch 1971, 1973). We use the resulting cladograms to draw hypotheses on the evolution of aposematism and toxicity in poison frogs.

\section{Materials and methods}

\section{Selection of gene fragments}

To get an overview of phylogenetic relationships among poison frogs, we selected a fragment of the 16S rRNA gene (approximately 540 base pairs) which has been used in most previous molecular studies that included dendrobatids (e.g. Ruvinsky \& Maxson 1996, Vences et al. 2000, Clough \& Summers 2000). Thus, a large number of sequences of this fragment was available and could readily be combined with the newly obtained data to the largest data set so far analysed in hyloid frogs (i.e. about 100 sequences). Because the $16 \mathrm{~S}$ rRNA gene is known to be informative regarding dendrobatid relationships, and previous cladograms based entirely on this fragment (Vences et al. 2000) corresponded well with a cladogram obtained by combination of three genes (Clough \& Summers 2000), we used the complete set of available 16S rDNA sequences for a first identification of major dendrobatid clades.

To find higher support for the non-monophyly of aposematic and non-aposematic dendrobatids, we sequenced additional $16 \mathrm{~S}$ rDNA and 12S rDNA fragments (approximately 510 and 360 base pairs, respectively) from representatives of the major dendrobatid clades (Table 1) as identified in the initial 16S rDNA survey.

\section{DNA extraction, amplification and sequencing}

DNA was extracted using QIAmp tissue extraction kits (Qiagen) from tissue samples (hindleg muscle, either fresh or pre- 
Table 1. Major clades of cryptic dendrobatids identified by our analysis (undescribed and unidentified species not listed). Clades 1- 4 of Colostethus are named in accordance with Fig. 1. Only species for which genetic data are available are included.

\begin{tabular}{lll}
\hline Name of lineage & Species included & Probable sister group \\
\hline Colostethus clade 1 & C. humilis, C. marchesianus, C. talamancae, C. trilineatus & Allobates \\
Colostethus clade 2 & C. baeobatrachus, C. degranvillei, C. palmatus, C. stepheni & Mannophryne + Nephelobates \\
Colostethus clade 3 & C. pratti & Epipedobates (W Andean clade) \\
Colostethus clade 4 & C. bocagei, C. subpunctatus & Cryptophyllobates? \\
Mannophryne & M. collaris, M. herminae & Nephelobates \\
Nephelobates & N. molinarii & Mannophryne \\
\hline
\end{tabular}

served in $98 \%$ EtOH). We used the primers 16Sar-L (light chain; 5'-CGC CTG TTT ATC AAA AAC AT-3') and 16Sbr-H (heavy chain; 5'-CCG GTC TGA ACT CAG ATC ACG T-3') of Palumbi et al. (1991) to amplify a portion of the $16 \mathrm{~S}$ ribosomal RNA gene in all samples available (in the following referred to as 16S). We used the primers 16SL3 (light chain; AGC AAA GAH YWW ACC TCG TAC CTT TTG CAT) and $16 \mathrm{Sa}-\mathrm{H}$ (heavy chain; reverse of $16 \mathrm{Sar}-\mathrm{L}$ ) to amplify an additional section of the mitochondrial $16 \mathrm{~S}$ ribosomal RNA gene (in the following referred to as 16S-B); and the primers 12SAL (light chain; 5'-AAA CTG GGA TTA GAT ACC CCA CTA T-3') and 12SB-H (heavy chain; 5'-GAG GGT GAC GGG CGG TGT GT-3') to amplify a section of the mitochondrial $12 \mathrm{~S}$ ribosomal RNA gene. PCR protocols for the $16 \mathrm{~S}$ fragments were as follows. Initial denaturation step: $90 \mathrm{~s}$ at $94{ }^{\circ} \mathrm{C}$; 33 cycles: denaturation $45 \mathrm{~s}$ at $94{ }^{\circ} \mathrm{C}$, primer annealing for $45 \mathrm{~s}$ at $55^{\circ} \mathrm{C}$, extension for $90 \mathrm{~s}$ at $72{ }^{\circ} \mathrm{C}$. PCR protocol for the $12 \mathrm{~S}$ fragment was as follows. 35 cycles: denaturation $45 \mathrm{~s}$ at $94{ }^{\circ} \mathrm{C}$, primer annealing for $60 \mathrm{~s}$ at $50{ }^{\circ} \mathrm{C}$, extension for $120 \mathrm{~s}$ at $74{ }^{\circ} \mathrm{C}$. PCR products were purified using QIAquick purification kits (Qiagen). We sequenced single-stranded fragments using an automatic sequencer (ABI 377). Voucher specimens (if maintained) and GenBank accession numbers of all sequences used for analysis are given in an Organisms Diversity and Evolution Electronic Supplement (http://www.senckenberg.de/odes/03-13.htm, Part 1). New sequences received the accession numbers AY263212-AY263269.

\section{Data analysis}

Sequences were aligned using the clustal option in the program Sequence Navigator (Applied Biosystems). A correct alignment of complete ribosomal RNA gene sequences should take into account any secondary structures (Kjer 1995). Considering the high number of taxa involved in our alignment, and the considerable uncertainties of alignment of hypervariable regions, we preferred instead a strongly conservative approach which excluded all regions of the gene fragments that could not be clearly aligned among all taxa, as recommended by Swofford et al. (1996). All positions with gaps in one or more taxa were excluded as well. Altogether, more that $30 \%$ of the positions from the $16 \mathrm{~S}$ alignment were excluded (original sequence lengths were between 520 and $540 \mathrm{bp}$ ), and a similar percentage was excluded from the $12 \mathrm{~S}$ and $16 \mathrm{~S}-\mathrm{B}$ alignments in the reduced set of taxa. Preliminary analyses that included the com- plete sequences and coded gaps either as missing data or as fifth character states yielded phylogenetic trees with topologies very similar to those described herein. This indicates that the excluded hypervariable regions bear only limited additional phylogenetic information, and justifies their exclusion.

Prior to phylogenetic analysis, we performed hierarchical likelihood ratio tests to evaluate which substitution model fits our data best. We used Modeltest (Posada \& Crandall 1998), version 3.06, in combination with PAUP*, version 4b8. Phylogenetic analyses were carried out with PAUP*, version $4 \mathrm{~b} 10$ (Swofford 2002). Heuristic searches were done under Maximum Likelihood (ML) and Maximum Parsimony (MP), using tree-bisection-reconnection (TBR) branch swapping, and random addition sequences with ten replicates. Bootstrap values (Felsenstein 1985) and Bayesian posterior probabilities were calculated to assess the robustness of topologies. Two thousand full heuristic bootstrap replicates were calculated using Neighbor-Joining and the substitution models suggested by Modeltest in both data sets, while only 100 ML replicates could be calculated for the combined data set because of computational restrictions.

In the Bayesian analysis, we ran 500,000 generations, sampling every tenth tree, using MrBayes software, version 2.01 (Huelsenbeck \& Ronquist 2001). Since Modeltest had suggested complex substitution models, we used the following settings in MrBayes: Nst $=6$, rates = invgamma, basefreq = estimate (the GTR $+\mathrm{I}+\mathrm{G}$ model). Based on empirical evaluation we set burn-in (the initial set of generations preceding convergence on stable likelihood values) at 50,000 generations in the $16 \mathrm{~S}$ rRNA data set, and at 10,000 in the combined data set.

For the testing of multiple alternative topologies we used the Shimodaira-Hasegawa-test (SH-test; Shimodaira \& Hasegawa 1999) as implemented in PAUP* (settings: full optimisation; 1,000 bootstrap replicates) which is the only non-parametric method currently considered as applicable to such problems under the ML optimality criterion (Whelan et al. 2001).

\section{Results}

For the $16 \mathrm{~S}$ rDNA data set (368 bp after exclusion of hypervariable regions), the hierarchical likelihood ratio tests in Modeltest selected a GTR $+\mathrm{I}+\mathrm{G}$ substitution 
model $(-\ln L=5072.91)$ with empirical base frequencies (freq $\mathrm{A}=0.3442 ;$ freqC $=0.1897$; freqG $=0.1995$; freq $\mathrm{T}$ $=0.2666)$ and substitution rates $([\mathrm{A}-\mathrm{C}]=3.0193 ;[\mathrm{A}-\mathrm{G}]$ $=5.1240 ;[\mathrm{A}-\mathrm{T}]=4.0070 ;[\mathrm{C}-\mathrm{G}]=0.4068 ;[\mathrm{C}-\mathrm{T}]=$ 26.4920; $[\mathrm{G}-\mathrm{T}]=1$ ), a proportion of invariable sites of 0.2915 , and a gamma distribution shape parameter of 0.4767. Maximum likelihood heuristic searches recovered four trees with the same highest likelihood score. These differed only in single aspects of the arrangement of terminal conspecific sequences. One of these trees is shown in Fig. 1.

For the combined $16 \mathrm{~S}$ and $12 \mathrm{~S}$ rDNA data set $(1,084$ bp after exclusion of hypervariable regions), the hierarchical likelihood ratio tests in Modeltest selected a TrN+I+G substitution model with empirical base frequencies (freqA $=0.3946$; freqC $=0.2080$; freqG $=$ 0.1422 ; freq $\mathrm{T}=0.2552)$ and substitution rates $([\mathrm{A}-\mathrm{G}]=$ $2.8980 ;[\mathrm{C}-\mathrm{T}]=6.1297$; all other rates $=1$ ), a proportion of invariable sites of 0.2479 , and a gamma distribution shape parameter of 0.4110 . Maximum likelihood analysis identified a single best tree $(-\ln L=7619.5$; Fig. 2$)$. MP analysis identified two most parsimonious trees (1,471 steps; consistency index 0.51 ; retention index 0.37). These were largely in agreement with the ML tree which needed 1,485 steps under the MP optimality criterion (consistency index 0.51 ; retention index 0.36 ). The strict consensus of the MP trees differed in the arrangement of the outgroups (Leptodactylus was the most basal leptodactylid) and was ambiguous regarding the sistergroup relationship of Cryptophyllobates azureiventris and Colostethus bocagei. However, most of the relevant placements, such as those of $C$. bocagei among the aposematic species, of Allobates femoralis sister to Colostethus talamancae, of Colostethus pratti sister to Epipedobates trivittatus, and of Hylodes sister to the dendrobatids, were also recovered by the MP searches.

Bootstrap values and Bayesian posterior probabilities coincided in defining several clades which were already indicated by the more inclusive analysis based on $16 \mathrm{~S}$ rDNA sequences only. The positions of Colostethus pratti as sister group of Epipedobates and of C. talamancae as sister group of Allobates were strongly confirmed (bootstrap values $>75 \%$, maximum posterior probabili- ties $=100 \%$ ), while the position of Colostethus bocagei and Cryptophyllobates was not supported by relevant scores. Dendrobatids clearly were monophyletic (bootstrap values $>95 \%$, posterior probability $=100 \%$ ). The genus Hylodes was identified as their sister group, but this grouping received no relevant support.

SH-tests significantly rejected all tested variants of the 'classic', currently accepted dendrobatid phylogeny (e.g. Myers et al. 1991) in which all cryptic species were arranged basally in the tree and the aposematic species (including Allobates femoralis) formed a monophyletic group $(\mathrm{P}<0.01)$. Also, alternative trees with modified positions of this species (remaining topology kept equal) were significantly rejected $(\mathrm{P} \leq 0.05)$. In contrast, other variants with modified positions of Cryptophyllobates azureiventris, Colostethus bocagei, Epipedobates trivittatus, or Colostethus pratti were not significantly rejected in most cases (see Electr. Suppl. 03-13, Parts 2 and 3, for alternative topologies tested and likelihood values). MP searches carried out by constraining monophyly of the aposematic dendrobatids resulted in 44 trees with a tree length of 1,528 steps, thus 57 steps more than the most parsimonious tree, and 43 steps more than the ML tree.

\section{Discussion}

\section{Combinability of sequences}

In this study, we assembled the most comprehensive dataset of dendrobatid sequences thus far, obtained by different working groups (e.g. Ruvinsky \& Maxson 1996, Clough \& Summers 2000, Vences et al. 2000). For 13 taxa (Allobates femoralis, Colostethus pratti, C. talamancae, Epipedobates trivittatus, Cryptophyllobates azureiventris, Dendrobates auratus, D. tinctorius, D. leucomelas, D. pumilio, D. sylvaticus, D. ventrimaculatus, Phyllobates lugubris, and $P$. vittatus), sequences we generated were available in addition to those of other research teams (see Electr. Suppl. 03-13, Part 1). Combining them, seven were placed as monophyletic units by our analysis, while all others clustered very close to

Fig. 1. Maximum likelihood tree obtained by heuristic searches, based on 368 base pairs of the 16S rRNA gene (all regions of ambiguous alignment and gapped positions excluded) in 86 dendrobatid sequences. Discoglossus pictus and Xenopus laevis were used as outgroups (not shown). First numbers at nodes are results of neighbor-joining bootstrapping (in percent; 2,000 replicates), second numbers are Bayesian posterior probabilities $(500,000$ generations, every tenth generation sampled, burn-in set at 10\%). Values are shown for nodes which received $>$ $50 \%$ bootstrap support or a posterior probability $>70 \%$. All analyses were carried out under a GTR+I+G substitution model selected by M odeltest. Sequences from previous works are marked with RM (Ruvinsky \& Maxson 1996), S (Clough \& Summers 2000, and other papers by K. Summers and colleagues), orV (Vences et al. 2000). Clades characterized by aposematic coloration are marked with "AP" in a grey box. Clades and genera of non-aposematic genera are named in accordance with Table 1. 


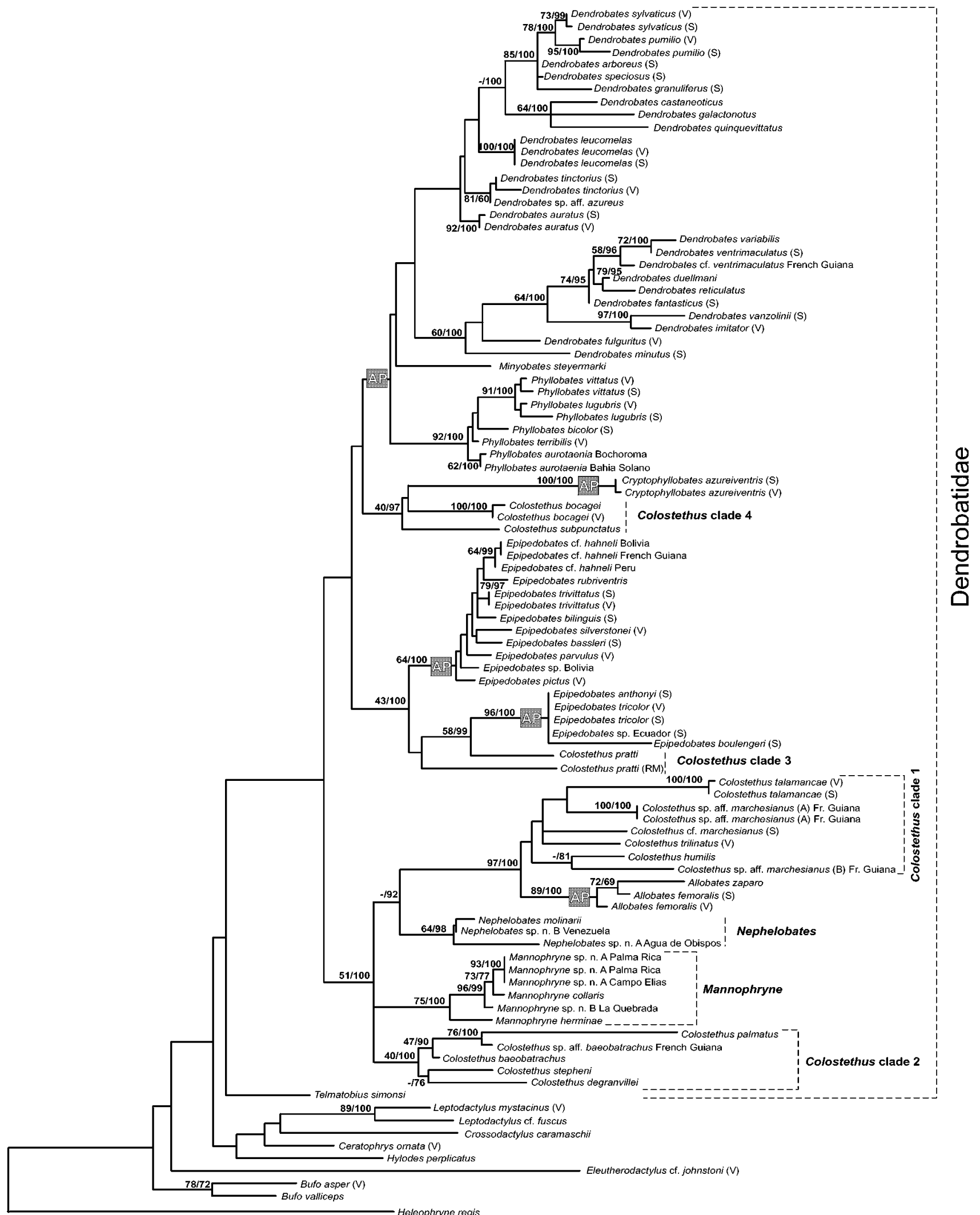




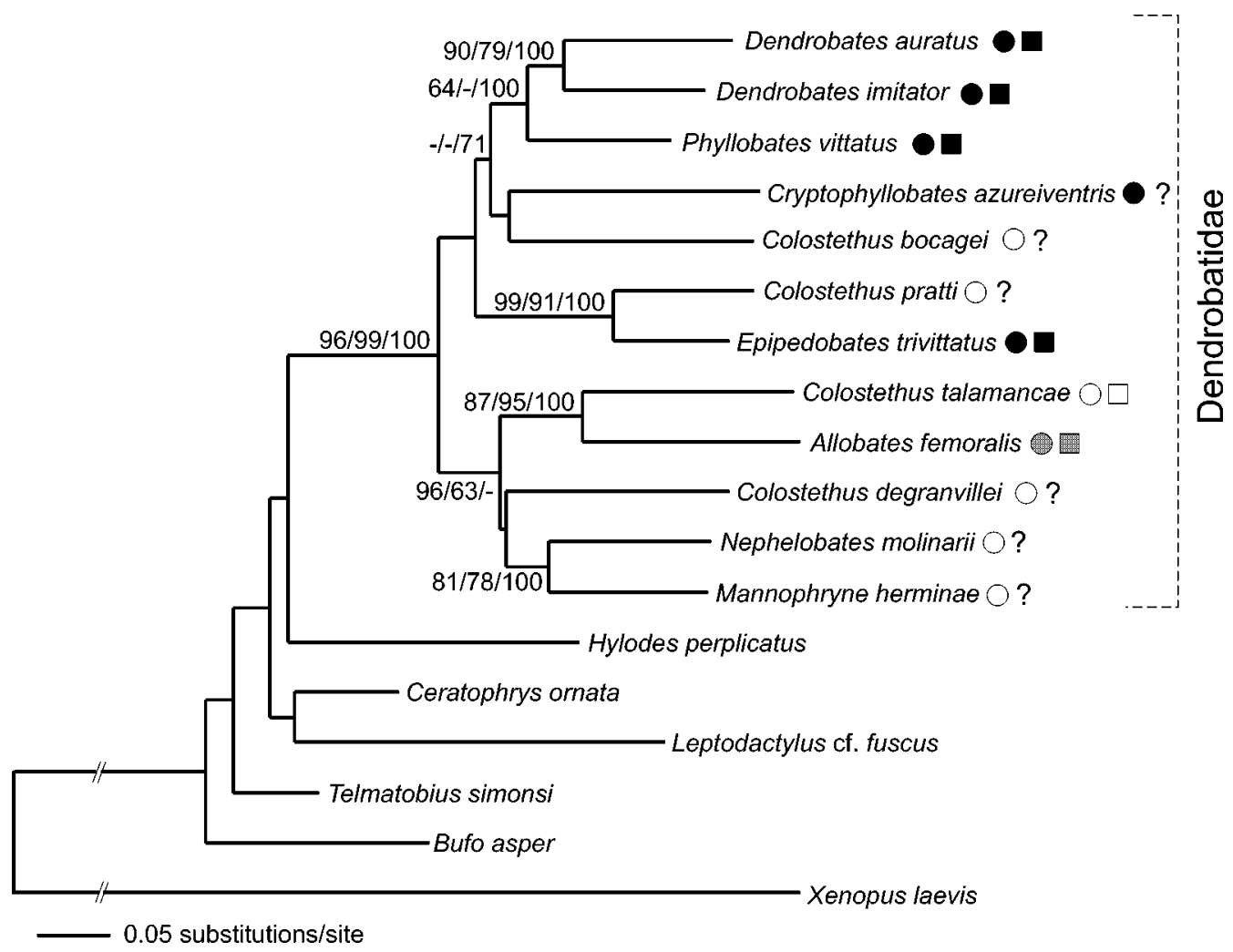

Fig. 2. Maximum likelihood tree obtained by heuristic searches (10 random-addition sequence replicates), based on 1084 base pairs of the $12 S$ and $16 S$ rRNA genes in selected representatives of the major dendrobatid lineages as identified by preliminary analysis (Fig. 1). Xenopus laevis was used as the outgroup. First numbers at nodes are results of maximum likelihood bootstrapping (in percent; 100 replicates), second numbers are results of maximum parsimony bootstrapping (in percent; 2,000 replicates), third numbers are Bayesian posterior probabilities $(500,000$ generations, every tenth generation sampled, burn-in set at $2 \%)$. Values are shown only for nodes that received support $>70 \%$ in at least one analysis. Circles denote coloration (black = aposematic, grey = near to aposematic, white $=$ non-aposematic), squares denote presence of skin alkaloids (black = present, grey = present in traces, white $=$ not present, $?=$ not yet tested).

each other (Fig. 1). In some cases (Dendrobates ventrimaculatus, D. tinctorius) these paraphyletic arrangements may have been caused by intraspecific variation. In other cases (species of Phyllobates, Colostethus prat$t i)$ the differences probably are more the result of different sequencing qualities and subsequent erroneous scoring of single positions in some sequences. This highlights that caution must be applied when comparing haplotypes from different sources at the population level (cf. Harris 2001). Nevertheless, none of the observed ambiguities resulted in alternative placements of conspecific specimens in different major dendrobatid lineages, confirming that it is possible to combine these different datasets for higher-level analyses.

\section{Taxonomic implications}

Our data indicate that dendrobatid taxonomy and classification at the species level are far from settled. Our samples show that some forms comprise genetically highly divergent taxa (Fig. 1) that, in our opinion, represent undescribed species (i.e. Colostethus sp. aff. baeobatrachus and $C$. sp. aff. marchesianus A and B, Epipedobates sp. Bolivia, Mannophryne sp. A and B, Nephelobates sp. A and B). In addition, in two cases our data indicate relatively high divergences between populations from the Guianan region and the upper Amazon basin which so far were considered conspecific. Total pairwise divergence in the $16 \mathrm{~S}$ rDNA fragment (including hypervariable regions) between Peruvian and French Guianan specimens were 4\% (21 substitutions) in Dendrobates ventrimaculatus, and $3 \%$ (16 substitutions) in Epipedobates cf. hahneli.

Dendrobates galactonotus has been suggested to be closely related to $D$. tinctorius by Silverstone (1975) based on morphological resemblance. Surprisingly, the $16 \mathrm{~S}$ phylogeny (Fig. 1) placed D. galactonotus as more related to sympatric $D$. castaneoticus and $D$. quinquevit- 
tatus, which are morphologically quite different (Silverstone 1975). Although bootstrap support for this placement was quite high, it should be interpreted cautiously until more sequence data for this species become available. The relatively low number of characters available for analysis may also explain why Epipedobates trivittatus does not cluster with E. bassleri and E. silverstonei, although Silverstone (1976) and Zimmermann \& Zimmermann (1988) grouped all three as an assemblage of morphologically and ethologically similar species.

Our data contribute significantly to the understanding of generic relationships within Dendrobatidae. By confirming that Cryptophyllobates azureiventris does not belong in a lineage with Epipedobates or Phyllobates, our data corroborate the validity of the genus Cryptophyllobates, recently erected for Phyllobates azureiventris Kneller \& Henle, 1985 (Lötters et al. 2000). Moreover, validity of the genera Mannophryne and Nephelobates as suggested by La Marca $(1992,1994)$ is strongly supported.

The isolated position of Minyobates steyermarki (type species of the genus Minyobates) at the basis of Dendrobates is surprising as well. The genus Minyobates was created for an assemblage of aposematic dwarf dendrobatids assumed to have cephalic amplexus (versus absent in Phyllobates and Dendrobates), based on observations in M. steyermarki by Myers (1987). Subsequent behavioural (Jungfer et al. 1996) and molecular observations (Clough \& Summers 2000, Vences et al. 2000) led to the transfer of the species $D$. fulguritus and D. minutus from Minyobates to Dendrobates and thus cast doubts on the validity of Minyobates. The isolated phylogenetic position of $M$. steyermarki, which occurs in a remote area of the Venezuelan table mountains, qualifies it as a key species to understand the evolution of derived mating systems among dendrobatids, and reinforces the validity of the genus Minyobates (which may be monotypic).

The identification of several well-defined groups in Epipedobates and Colostethus and the high degree of paraphyly characterizing these genera invoke the need for further partitioning, with the well-defined lineages (in part coinciding with species groups proposed by previous authors; Silverstone 1976, Rivero 1990) as generic units. However, we suggest waiting for genetic data on several crucial species, e.g. on the type species of Colostethus (C. latinasus) and its junior synonyms $H y$ loxalus (type species $C$. fuliginosus) and Prostherapis (C. inguinalis) (see Dubois 1981, Myers et al. 1991), and on the enigmatic Aromobates nocturnus, before changing the classification of these frogs.

\section{Sister group of the Dendrobatidae}

Our analysis strongly corroborated that aposematic and cryptic dendrobatids together form a monophyletic group. However, as in previous studies (Ruvinsky \& Maxon 1996, Vences et al. 2000), our data failed to resolve the position of this clade among hyloid frogs. We included, for the first time, representatives of all leptodactylid subfamilies (i.e. Ceratophryinae, Hylodinae, Leptodactylinae, Telmatobiinae). The combined tree (Fig. 2) placed Hylodes as sister group of the dendrobatids, but this placement received no support from bootstrapping or Bayesian analysis. In the preliminary exploration using the $16 \mathrm{~S}$ rDNA data set, the two available hylodines, Crossodactylus and Hylodes, were not combined as sister taxa. This certainly is an artefact of the relatively few informative positions, but it highlights that these two genera are significantly differentiated. Hylodines share several osteological characters with the Dendrobatidae (Lynch 1971). They are small to medium-sized, diurnal, stream-breeding frogs with complex optical communication systems (Hödl \& Amezquita 2001), phenetically similar to cryptic poison frogs. Whether this or another lineage may constitute the sister group of dendrobatids, it seems clear that the latter originated early within the initial hyloid radiation (Ruvinsky \& Maxson 1996), showing relatively deep divergences to all other hyloid subgroups.

\section{Multiple evolution of bright color and regional clades}

Our results indicate several cases of convergence or reversal with respect to bright color in dendrobatids (Fig. 3). The 'classic' hypotheses, with basal positions of Aromobates, Colostethus sensu lato, Mannophryne and Nephelobates and an arrangement of the bright colored taxa in one monophyletic lineage (e.g. Myers et al. 1991, Kaplan 1997), was significantly rejected by the SHtests. Unfortunately, the alkaloid content of several crucial taxa has not been assessed yet (Fig. 2), and therefore it can only be hypothesized that the bright color is in all instances an aposematic signal related to toxicity.

According to our trees, Allobates (brightly colored) is clearly nested within one clade of Colostethus sensu lato (generally cryptic; Edwards 1974, Coloma 1995). Colostethus pratti (cryptic; Edwards 1974) is placed as the sister group of one clade of Epipedobates sensu lato (generally aposematic). And Colostethus bocagei and C. subpunctatus (both cryptic; Edwards 1974) appear to be related to Cryptophyllobates (brightly colored). However, the quality of the available evidence differs among these examples.

The best-documented case is the positioning of Allobates within a Colostethus lineage (containing C. humilis, C. marchesianus, C. talamancae, and C. trilineatus; Fig. 1). Alternative placements of Allobates were significantly rejected by $\mathrm{SH}$-tests. Some populations of A. femoralis are not brightly colored but the majority is, 

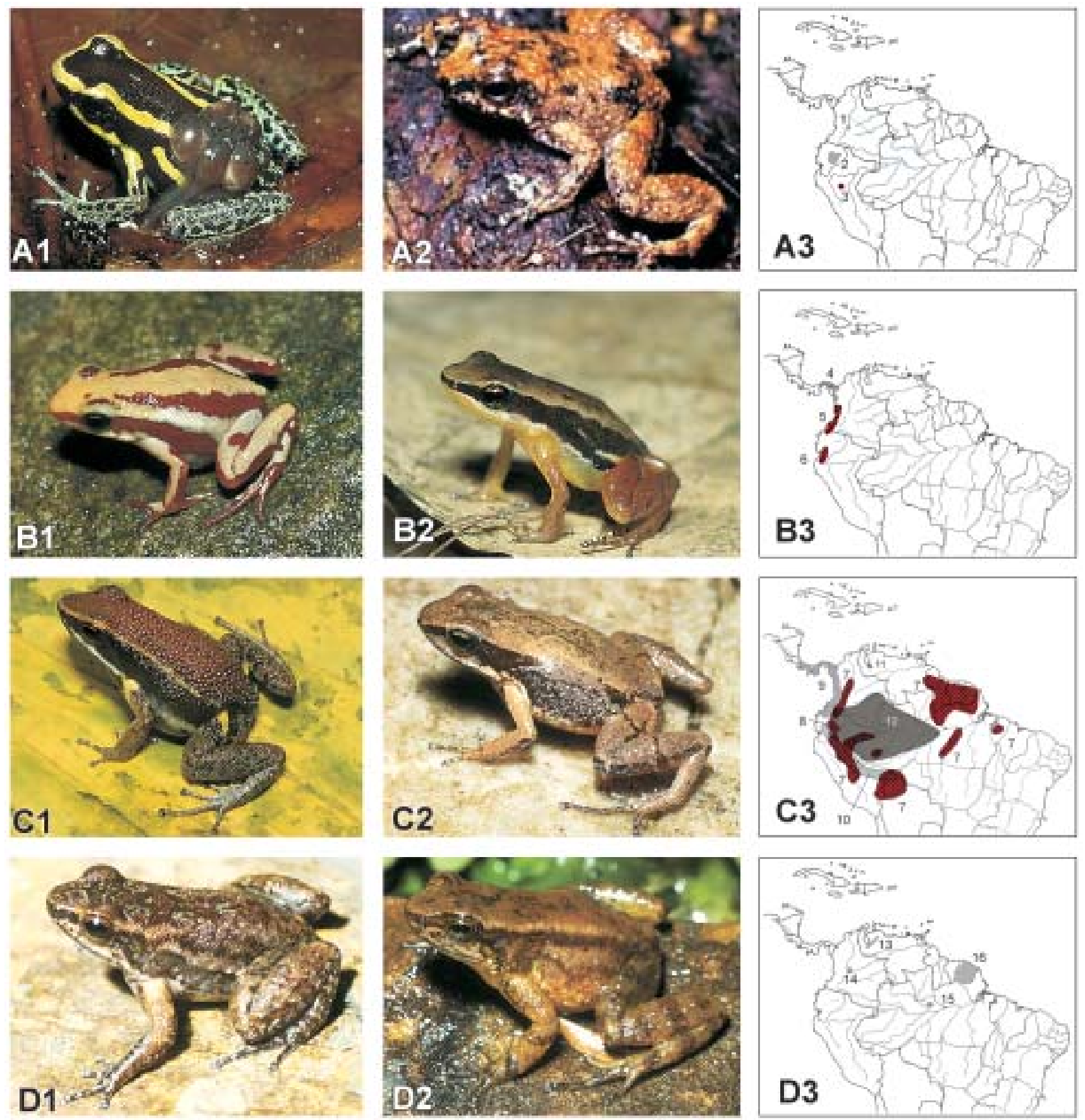

Fig. 3. Examples of live coloration of aposematic and non-aposematic dendrobatid frogs from distinct clades (Table 1, Fig. 1) identified through our analysis, and geographic distribution of all species from the respective clusters for which genetic data were available (undescribed and unidentified species not considered). In the distribution maps, red color marks areas of aposematic species, grey those of cryptic species. A. Cryptophyllobates and Colostethus clade 4: A1 Cryptophyllobates azureiventris; A2 Colostethus bocagei. B. Epipedobates (from west of the Andes) and Colostethus clade 3: B1 Epipedobates tricolor; B2 Colostethus pratti. C. Allobates and Colostethus clade 1: C1 Allobates zaparo; C2 Colostethus humilis. D. Mannophryne, Nephelobates and Colostethus clade 2: D1 Mannophryne herminae; D2 Nephelobates molinarii. Distribution areas are given for the following species: 1 Colostethus subpunctatus; 2 Colostethus bocagei; 3 Cryptophyllobates azureiventris; 4 Colostethus pratti; 5 Epipedobates boulengeri; 6 E. tricolor and E. anthonyi; 7 Allobates femoralis; 8 A. zaparo; 9 Colostethus talamancae; 10 C. trilineatus; 11 C. humilis; 12 C. marchesianus; 13 Mannophryne and Nephelobates; 14 Colostethus palmatus; 15 C. stepheni; 16 C. baeobatrachus and C. degranvillei. Distributional information is based on Silverstone $(1975,1976)$, Schulte (1999), De la Riva et al. (2000), Lescure \& Marty (2001), Lima \& Caldwell (2001), Caldwell et al. (2002), Caldwell \& Lima (2003), and the Amphibian Species of the World database (http://research.amnh.org/herpetology/amphibia/) as of October 2002. Photographs by K.-H. Jungfer (A1, B1, B2, C1), M. Read (A2), and M. Vences (C2, D1, D2). 
having a light yellow or gold labial, dorsolateral, and ventrolateral stripes, and bright yellow or red axillar and inguinal spots (Silverstone 1976). Also Allobates zaparo (Silverstone, 1976) comb. nov. (here transferred from Epipedobates) clearly is aposematic with a bright reddish dorsum (Jungfer 1989). Traces of skin alkaloids have been found in one population of A. femoralis (see Daly et al. 1987). A. zaparo has not been tested (J.W. Daly, pers. comm.). As Allobates is deeply nested among other cryptic species (Fig. 1), the most parsimonious explanation is that they acquired their brightness independently from species of Epipedobates, some of which have similar patterns (Jungfer 1989). The distinctive karyotype of Allobates femoralis (Aguiar-Jr. et al. 2002) and the structure of its spermatozoa (Aguiar-Jr. et al. 2003) also favour a relationship with species of Colostethus rather than those of Epipedobates.

Batesian mimicry has been invoked to explain the similarity between the non-toxic Eleutherodactylus gaigeae (family Leptodactylidae) from Central America and a highly toxic sympatric species, Phyllobates lugubris (see Myers \& Daly 1983). Considering recent indications for mimicry phenomena in frogs (Symula et al. 2001, Schaefer et al. 2002), it might be worth testing if similar explanations could be invoked for Allobates and sympatric Amazonian Epipedobates species (Jungfer 1989), although Allobates femoralis has been thought of as the model for a non-toxic mimic leptodactylid frog, Lithodytes lineatus (see Nelson \& Miller 1971).

In Colostethus pratti, the shanks are orange and the venter is yellowish, but in general the coloration is cryptic and much more similar to most other Colostethus than to the brightly colored species of Epipedobates with which it clusters (Fig. 1), and which generally have light dorsolateral lines (absent in a few species only) and/or reddish dorsum and/or bright axillar, inguinal and/or calf spots. Nevertheless, the pattern alone (i.e. dorsolateral lines) of C. pratti and E. anthonyi and E. tricolor (but not E. boulengeri) is similar, and E. tricolor is extremely variable in coloration (Edwards 1974, Silverstone 1976). Moreover, it might be relevant that this placement correlates relatively well with geographic distributions of the lineages involved, and of one morphological character (presence of a swollen third finger in males) thought to be phylogenetically informative in dendrobatids (e.g. Myers et al. 1991, but see Coloma 1995). This character is shared, on the one hand, by a large number of Colostethus species (Coloma 1995) including $C$. pratti and at least 11 other species of the genus (i.e. Colostethus sensu stricto because the type species, C. latinasus, is involved; group IV of Rivero 1990). On the other hand, several Epipedobates (E. tricolor, E. boulengeri, E. espinosai, and E. anthonyi) also have this character (Myers 1991). The latter are repre- sentatives of their genus from west of the Andes only (we lack information for the two other Epipedobates species that occur west of the Andes, E. andinus and E. erythromos). Three of these, for which data are available, form a monophyletic lineage to the exclusion of other Epipedobates (Fig. 1). Nine out of the 12 Colostethus having a swollen third finger in males (including $C$. pratti which clusters with the three Epipedobates species mentioned; Fig. 1) occur in this area as well (Rivero 1990, Coloma 1995). It is therefore tempting to hypothesize that the western Andean Epipedobates (including the type species E. tricolor) arose out of a western Andean Colostethus cluster with which they still share the swollen third finger apomorphy. In this scenario, the ancestor of the radiation of Epipedobates from east of the Andes (for which the name Phobobates would become available in the case of generic splitting; Zimmermann \& Zimmermann 1988) acquired bright coloration independently from the western Andean species. However, this hypothesis remains tentative because (i) alternative positions of Colostethus pratti could not be significantly excluded, (ii) $C$. pratti was the only Colostethus from west of the Andes included in our analysis, and (iii) at least one species with a swollen third finger in males (i.e., C. stepheni from the Amazon basin) is unrelated to Epipedobates (Fig. 1), demonstrating the occurrence of convergence or reversal also in this morphological character (Grant et al. 1997).

The least supported example for convergence in bright color evolution regards Colostethus bocagei and C. subpunctatus. As in previous analyses (Vences et al. 2000), the position of $C$. bocagei was not well resolved. This species was placed close to Cryptophyllobates azureiventris (Figs. 1, 2), a further enigmatic species formerly included in Epipedobates and now removed from it (Lötters et al. 2000). Colostethus subpunctatus has distinct orange color on the ventral limb surfaces, but both $C$. bocagei and $C$. subpunctatus clearly have a cryptic brownish dorsal surface (Edwards 1974) as opposed to the light yellow or orange labial, dorsolateral and lateral lines of Cryptophyllobates. Again, it is conspicuous that these taxa show little resemblance in coloration but occur in largely the same general area, namely the Amazonian (eastern) versant of the Andes or within the Cordillera Oriental (C. subpunctatus). However, their position must be considered as unresolved, as indicated by the low bootstrap values supporting their placement and the extremely small differences in log-likelihood scores of alternative topologies.

Beside the three Colostethus lineages discussed in the previous paragraphs (C. pratti; C. bocagei/subpunctatus; $C$. humilis/marchesianus/talamancae/trilineatus), our analysis supports another major clade in this (clearly paraphyletic) genus. It comprises C. baeobatrachus, C. degranvillei, C. palmatus and C. stepheni. The mem- 
bers of this clade, which are distributed in the northern arc of South America, are extraordinary in several respects. Colostethus degranvillei and C. stepheni, which are placed as sister species, show unique, derived reproductive modes with endotrophic tadpoles (Lescure 1984, Juncá et al. 1994). Colostethus palmatus also has been hypothesized to exhibit complex behavioural patterns and to be the possible sister group of Mannophryne (La Marca 1995).

In the future, more comprehensive analyses may reveal more large clades of non-aposematic dendrobatids, restricted to particular regions. In the Venezuelan Andes, Myers et al. (1991) described a large nocturnal dendrobatid as a new genus, Aromobates, but other relatively large taxa from this area (e.g. Colostethus leopardalis) may have affinities to this species as well (Mijares-Urrutia 1991; authors' pers. observ.). Also, our analysis did not include any species of the Colostethus groups I (from the northern and central Andes), III (from the lower Amazon basin and the Atlantic forests of Brazil) or V (from the Cordillera Oriental of Colombia), nor additional taxa not allocated to any species group (Rivero 1990). These may prove to constitute further geographically distinct monophyletic radiations.

The examples discussed herein suggest a strong biogeographic component in dendrobatid evolution. The Amazonian basin is likely to be a major reservoir of dendrobatid lineages, several of which seem to have dispersed out of this region into Central America (e.g. Colostethus sensu stricto, Dendrobates) or into the Andes (e.g. Colostethus humilis; La Marca et al. in press). However, the Andes especially have played a major role, with some lineages evolving west or east of this mountain massif (e.g. Epipedobates/Colostethus) or with their diversity center in the higher altitudes of the Andes themselves (e.g. Mannophryne, Nephelobates). It is likely that the separate evolution of these lineages was initiated by vicariant processes. Apparently, several of these lineages that radiated in geographic isolation gave independent rise to clades with bright color patterns and probably with skin alkaloids.

The evidence from our trees makes multiple (parallel) evolution of these chromatic specializations more likely than their loss in some lineages. Taking the example with highest statistical support, the generally brightly colored Allobates is nested among cryptic forms. A reversal hypothesis implies multiple loss of bright color and is thereby less parsimonious than the assumption that its acquisition in Allobates occurred independently from other aposematic lineages. Similar arguments can be used in the case of Cryptophyllobates, although the phylogeny is not well supported in this case. In Epipedobates, a basal acquisition of bright color and its loss in Colostethus pratti is as parsimonious (two steps) as its independent acquisition in the two regional Epipedo- bates radiations (east and west of the Andes). We did not identify any example of cryptic species nested among aposematic species that would unambiguously indicate a reversal.

Similar to all alkaloid-bearing aposematic anurans but unlike most other frogs, cryptic dendrobatids are diurnal with only few exceptions (Myers et al. 1991; Vences et al. 1998; authors' pers. observ.). Diurnality is crucial for the evolution of aposematism which is directed against optically-oriented diurnal predators, and a similar rationale applies if the bright color of some dendrobatids is related to intraspecific communication rather than the warning of predators (Lima \& Caldwell 2001). Therefore, ancestral diurnality may have been an important predisposition for the multiple (parallel) evolution of aposematic color in several regional radiations of the Dendrobatidae.

\section{Acknowledgements}

We are grateful to J.-C. Baloup, M. Blanc, F. Catzeflis, P. Charles-Dominique, J. W. Daly, P. Gaucher, K. Hauck, K.-H. Jungfer, M. Kneller, H. Lüddecke and J. C. de Massary, who supplied tissue samples or unpublished data. M. Read kindly allowed use of his picture of Colostethus bocagei. S. Lochon kindly assisted in obtaining collecting and export permits. The Universidad de lo Andes, Instituto de Geografía y Conservación de los Recursos Naturales, Mérida, provided logistic support for our collecting trips in Venezuela. C. F. B. Haddad is grateful to CNPq for a research fellowship.

\section{References}

Aguiar-Jr., O., Garda, A. A., Lima, A. P., Colli, G. R., Bào, S. N. \& Recco-Pimentel, S. M. (2003): Biflagellate spermatozoon of the poison-dart frogs Epipedobates femoralis and Colostethus sp. (Anura, Dendrobatidae). J. Morphol. 255: 114-121.

Aguiar-Jr., O., Lima, A. P., Giaretta, A. A. \& Recco-Pimentel, S. M. (2002): Cytogenetic analysis of four poison frogs of the Epipedobates genus (Anura: Dendrobatidae). Herpetologica 58: 293-303.

Bourne, G. R., Collins, A. C., Holder, A. M. \& McCarthy, C. L. (2001): Vocal communication and reproductive behavior of the frog Colostethus beebei in Guyana. J. Herpetol. 35: 272-281.

Caldwell, J. P. (1996): The evolution of myrmecophagy and its correlates in poison frogs (family Dendrobatidae). J. Zool. London 240: 75-101.

Caldwell, J. P. (1997): Pair bonding in spotted poison frogs. Nature 385: 211

Caldwell, J. P. \& Lima, A. P. (2003): A new Amazonian species of Colostethus with a nidicolous tadpole. Herpetologica 59: 218-233. 
Caldwell, J. P., Lima, A. P. \& Keller, C. (2002): Redescription of Colostethus marchesianus (Melin, 1941) from its type locality. Copeia 2002: 157-165.

Clough, M. E. \& Summers, K. (2000): Phylogenetic systematics and biogeography of the poison frogs: evidence from mitochondrial DNA sequences. Biol. J. Linn. Soc. 70: $515-540$

Coloma, L.A. (1995): Ecuadorian frogs of the genus Colostethus (Anura: Dendrobatidae). Univ. Kansas Nat. Hist. Mus. Misc. Publ. 87: 1-71.

Daly, J. W., Andriamaharavo, N. R., Andriantsiferana, M. \& Myers, C. W. (1996): Madagascan poison frogs (Mantella) and their skin alkaloids. Amer. Mus. Novitates 3177: 1-34.

Daly, J. W., Gusovsky, F., Myers, C. W., Yotsu-Yamashita, M. \& Yasumoto, T. (1994a): First occurrence of tetrodoxin in a dendrobatid frog (Colostethus inguinalis), with further reports for the bufonid genus Atelopus. Toxicon 32: 279-285.

Daly, J. W., Myers, C. W. \& Whittaker, N. (1987): Further classification of skin alkaloids from Neotropical poison frogs (Dendrobatidae), with a general survey of toxic/noxious substances in the Amphibia. Toxicon 25: 1023-1095.

Daly, J. W., Secunda, S. I., Garraffo, H. M., Spande, T. F., Wisnieski, A. \& Cover, J. F., jr. (1994b): An uptake system for dietary alkaloids in poison frogs (Dendrobatidae). Toxicon 32: 657-663.

De La Riva, I., Köhler, J., Lötters, S. \& Reichle, S. (2000) Ten years of research on Bolivian amphibians: updated checklist, distribution, taxonomic problems, literature and iconography. Revta Española Herpetol. 14: 19-164.

Dubois, A. (1981): Liste des genres et sous-genres nominaux de Ranoidea (Amphibiens Anoures) du monde, avec identification de leurs espèces-types: conséquences nomenclaturales. Monit. Zool. Ital. 13 (Suppl. XV): 225-284.

Duellman, W. E. \& Trueb, L. (1986): Biology of Amphibians. McGraw-Hill, New York.

Edwards, S. R. (1974): A phenetic analysis of the genus Colostethus (Anura: Dendrobatidae). PhD Dissertation, University of Kansas, Lawrence.

Felsenstein, J. (1985): Confidence limits on phylogenies: an approach using the bootstrap. Evolution 39: 783-791.

Frost, D. R. (ed.) (1985): Amphibian Species of the World. A Taxonomic and Geographical Reference. Allen Press and The Association of Systematics Collections, Lawrence, Kansas.

Glaw, F., Köhler, J., Hofrichter, R. \& Dubois, A. (1998): Systematik der Amphibien. Liste der rezenten Familien, Gattungen und Arten. Pp. 252-258 in: Hofrichter, R. (ed.) Amphibien. Naturbuch Verlag, Augsburg.

Grant, T., Humprey, E. C. \& Myers, C. W. (1997): The median lingual process of frogs: a bizarre character of Old World ranoids discovered in South American dendrobatids. Amer. Mus. Novitates 3212: 1-40.

Harris, D. J. (2001): Reevaluation of 16 S ribosomal RNA variation in Bufo (Anura: Amphibia). Mol. Phylog. Evol. 19: 326-329.

Hillis, D. M. (1996): Inferring complex phylogenies. Nature 383: 130-131.

Hödl, W. \& Amezquita, A. (2001): Visual signalling in anuran amphibians. Pp. 221-241 in: Ryan, M. (ed.) Frogs Speaking. Recent Advances in the Study of Anuran Communication. Smithsonian Institution Press, Washington.
Huelsenbeck, J. P. \& Ronquist, F. (2001): MrBayes: Bayesian inference of phylogenetic trees. Bioinformatics 17: 754-755.

Juncá, F. A., Altig, R. \& Gascon, C. (1994): Breeding biology of Colostethus stepheni, a dendrobatid frog with a nontransported nidicolous tadpole. Copeia 1994: 147-750.

Jungfer, K.-H. (1989): Pfeilgiftfrösche der Gattung Epipedobates mit rot granuliertem Rücken aus dem Oriente von Ecuador und Peru. Salamandra 25: 81-98.

Jungfer, K.-H., Birkhahn, H., Külpmann, V. \& Wassmann, K. (1996): Haltung und Fortpflanzung von Dendrobates fulguritus Silverstone, 1975, mit Anmerkungen zur Gattung Minyobates Myers, 1987. Herpetofauna 194: 19-27.

Kaplan, M. (1997): A new species of Colostethus from the Sierra Nevada de Santa Marta (Colombia) with comments on intergeneric relationships within the Dendrobatidae. J. Herpetol. 31: 369-375.

Kjer, K. M. (1995): Use of rRNA secondary structure in phylogenetic studies to identify homologous positions: an example of alignment and data presentation from frogs. Mol. Phylog. Evol. 4: 314-330.

La Marca, E. (1985): A new species of Colostethus (Anura: Dendrobatidae) from the Cordillera de Mérida, northern Andes, South America. Occas. Pap., Mus. Zool., Univ. Michigan 710: 1-10.

La Marca, E. (1992): Catálogo taxonómico, biogeográfico y bibliográfico de las ranas de Venezuela. Cuad. Geogr. Univ. Los Andes, Mérida 9: 1-197.

La Marca, E. (1994): Descripción de un género nuevo de ranas (Amphibia: Dendrobatidae) de la Cordillera de Mérida, Venezuela. Anuario de Investigación 1991, I.G.C.R.N., Universidad de Los Andes, Mérida 1991: 39-41.

La Marca, E. (1995): Biological and systematic synopsis of a genus of frogs from northern mountains of South America (Anura: Dendrobatidae: Mannophryne). Bull. Maryland Herpetol. Soc. 31: 40-77.

La Marca, E., Vences, M. \& Lötters, S. (in press): Rediscovery and mitochondrial relationships of the dendrobatid frog Colostethus humilis suggest parallel colonization of the Venezuelan Andes by poison frogs. Stud. Neotr. Fauna Envir.

Lescure, J. (1984): Las larvas de Dendrobatidae. II Reunion Iberoamer. Cons. Zool. Vert., pp. 37-44.

Lescure, J. \& Marty, C. (2001): Atlas des Amphibiens de Guyane. Museum National d'Histoire Naturelle, Paris.

Lima, A. P. \& Caldwell, J. P. (2001): A new Amazonian species of Colostethus with sky blue digits. Herpetologica 57: $180-189$.

Lötters, S. \& Vences, M. (1998): Mimikry und Mimese. Pp. 181-185 in: Hofrichter, R. (ed.) Amphibien. Naturbuch Verlag, Augsburg.

Lötters, S., Jungfer, K.-H. \& Widmer, A. (2000): A new genus of aposematic poison frog (Amphibia: Anura: Dendrobatidae) from the upper Amazon basin with notes on its reproductive behaviour and tadpole morphology. Jhrh. Ges. Naturk. Württemberg 156: 233-243.

Lynch, J. D. (1971): Evolutionary relationships, osteology, and zoogeography of leptodactyloid frogs. Misc. Publ. Mus. Nat. Hist. Univ. Kansas 53: 1-238.

Lynch, J. D. (1973): The transition from archaic to advanced frogs. Pp. 133-182 in: Vial, J. L. (ed.) Evolutionary Biology 
of the Anurans: Contemporary Research on Major Problems. University of Missouri Press, Columbia.

Mijares-Urrutia, A. (1991): Descripción del renacuajo de Colostethus leopardalis Rivero con algunos comentarios sobre su historia natural. Amphibia-Reptilia 12: 145-152.

Myers, C. W. (1987): New generic names for some Neotropical poison frogs (Dendrobatidae). Pap. Avul. Zool. 36: 301-306.

Myers, C. W. (1991): Distribution of the dendrobatid frog Colostethus chocoensis and description of a related species occurring macrosympatrically. Am. Mus. Novitates 3010: $1-15$.

Myers, C. W. \& Daly, J. W. (1983): Dart-poison frogs. Scientific American 248: 120-133.

Myers, C. W., Paolillo, A. \& Daly, J. W. (1991): Discovery of a defensively malodorous and nocturnal frog in the family Dendrobatidae: phylogenetic significance of a new genus and species from the Venezuelan Andes. Am. Mus. Novit. 3002: $1-33$.

Nelson, C. E. \& Miller, G. A. (1971): A possible case of mimicry in frogs. Herpetol. Rev. 3: 109.

Palumbi, S., Martin, A., Romano, S., McMillan, W. O., Stice, L. \& Grabowski, G. (1991): The Simple Fool's Guide to PCR. Version 2. Honululu, Hawai.

Posada, D. \& Crandall, K. A. (1998): MODELTEST: testing the model of DNA substitution. Bioinformatics 14: 817-818.

Rivero, J. A. "1988” (1990): Sobre las relaciones de las especies del género Colostethus (Amphibia; Dendrobatidae). Mem. Soc. Cienc. Nat. La Salle 48: 3-32.

Rivero, J. A. \& Serna, M. A. "1988” (1989): La identificación de los Colostethus (Amphibia, Dendrobatidae) de Colombia. Carib. J. Sci. 24: 137-154.

Ruvinsky, I. \& Maxson, L. R. (1996): Phylogenetic relationships among bufonid frogs (Anura: Neobatrachia) inferred from mitochondrial DNA sequences. Mol. Phylog. Evol. 5: 533-547.

Schaefer, H.-C., Vences, M. \& Veith, M. (2002): Molecular phylogeny of Malagasy poison frogs, genus Mantella (Anura: Mantellidae): homoplastic evolution of colour pattern in aposematic amphibians. Org. Divers. Evol. 2: 97-105.

Schulte, R. (1999): Pfeilgiftfrösche. Artenteil - Peru. Inibico, Waiblingen.

Shimodaira, H. \& Hasegawa, M. (1999): Multiple comparison of log-likelihoods with applications to phylogenetic inference. Mol. Biol. Evol. 16: 1114-1116.

Silverstone, P. A. (1975): A revision of the poison-arrow frogs of the genus Dendrobates Wagler. Nat. Hist. Mus. Los Angeles Co. Sci. Bull. 21: 1-55.
Silverstone, P. A. (1976): A revision of the poison-arrow frogs of the genus Phyllobates Bibron in Sagra (family Dendrobatidae). Nat. Hist. Mus. Los Angeles Co. Sci. Bull. 27: $1-53$.

Summers, K. \& Clough, M. E. (2001): The evolution of coloration and toxicity in the poison frog family (Dendrobatidae). Proc. Natl Acad. Sci. USA 98: 6227-6232.

Summers, K., Bermingham, E., Weigt, L., McCafferty, S. \& Dahlstrom, L. (1997): Phenotypic and genetic divergence in three species of dart-poison frogs with contrasting parental behavior. J. Heredity 88: 8-13.

Summers, K., Weight, L. A., Boag, P. \& Bermingham, E. (1999): The evolution of female parental care in poison frogs of the genus Dendrobates: evidence from mitochondrial DNA sequences. Herpetologica 55: 254-270.

Swofford, D. L. (2002): PAUP*. Phylogenetic Analysis Using Parsimony (* and other methods), Version 4b10. Sinauer Associates, Sunderland, Massachusetts.

Swofford, D. L., Olsen, G. J., Waddell, P. J. \& Hillis, D. M. (1996): Phylogenetic inference. Pp. 407-514 in: Hillis, D. M., Moritz, C. \& Mable, B. K. (eds.): Molecular Systematics. 2nd Edition. Sinauer, Sunderland, Massachusetts.

Symula, R., Schulte, R. \& Summers, K. (2001): Molecular phylogenetic evidence for a mimetic radiation in Peruvian poison frogs supports a Müllerian mimicry hypothesis. Proc. R. Soc. Lond. B 268: 2415-2421.

Toft, C. A. (1995): Evolution of diet specialization in poisondart frogs (Dendrobatidae). Herpetologica 51: 202-216.

Vences, M., Glaw, F. \& Böhme, W. (1998): Evolutionary correlates of microphagy in alkaloid-containing frogs (Amphibia: Anura). Zool. Anz. 236: 217-230.

Vences, M., Kosuch, J., Lötters, S., Widmer, A., Köhler, J., Jungfer, K.-H. \& Veith, M. (2000): Phylogeny and classification of poison frogs (Amphibia: Dendrobatidae), based on mitochondrial $16 \mathrm{~S}$ and $12 \mathrm{~S}$ ribosomal RNA gene sequences. Mol. Phylog. Evol. 15: 34-40.

Whelan, S., Liò, P. \& Goldman, N. (2001): Molecular phylogenetics: state-of-the-art methods for looking into the past. Trends in Genetics 17: 262-272.

Wiens, J. J. \& Hollingsworth, B. D. (2000): War of the iguanas: conflicting molecular and morphological phylogenies and long-branch attraction in iguanid lizards. Syst. Biol. 49: $143-159$.

Zimmermann, H. \& Zimmermann, E. (1988): Etho-Taxonomie und zoogeographische Artengruppenbildung bei Pfeilgiftfröschen (Anura: Dendrobatidae). Salamandra 24: 125-160.

Zwickl, D. J. \& Hillis, D. M. (2002): Increased taxon sampling greatly reduces phylogenetic error. Syst. Biol. 51: 588-598. 